\title{
Research on Integrated On-Site Teaching Model of Theory and Practice of Automobile Service Engineering Specialty
}

\author{
Enyuan Zhang ${ }^{1, a}$ \\ ${ }^{1}$ College of Automobile \& Civil Engineering Beihua University Jilin, Jilin Province, China \\ aE-mail: zey9815 @163.com
}

Keywords: Integration of theory and practice, On-Site Teaching, Teaching model, Automobile service engineering

\begin{abstract}
Integrated on-site teaching model of theory and practice integrate theory teaching with practice, truly linked theory with practice, helps improve students' understanding of professional theoretical knowledge, develop students' good practical ability and hands-on ability, improve the quality of talent training in application-oriented universities. This paper takes automobile service engineering as an example, explored the implementation of integrated on-site teaching model of theory and practice, it has certain reference significance to the teaching reform of auto specialty in local undergraduate colleges in transition.
\end{abstract}

\section{Introduction}

In 2017, china's auto production and sales completed 29.015 million vehicles and 28.887 million vehicles respectively, an increase of $3.2 \%$ and $3 \%$ over the same period of the previous year, the world's first for nine consecutive years reelection. By the end of 2017, there are 310 million vehicles in china, among them, 217 million cars. ${ }^{[1]}$ Such a huge car aftermarket, need a large number of knowledgeable and skilled automotive service professionals. Automobile service engineering major is a highly applied specialty, stress on practice teaching, strengthening the training of applied talents. The traditional mode of undergraduate education overemphasizes the instillation of knowledge, ability training is weak. Integration of theory and practice teaching mode has achieved good results in the education of secondary and higher vocational colleges occupation etc, it is suitable for the teaching of related courses in automobile service engineering. ${ }^{[2]}$

\section{The Current Status of Teaching Model}

Practice plays an important role in the process of training applied talents. The automobile service engineering major requires the training of practical skills while conducting theoretical teaching, emphasis on training students' practical application ability. ${ }^{[3]}$ However, the automobile service engineering major in many local universities is still using the traditional teaching model, teacher-centered "cramming" teaching, emphasis on imparting knowledge, often weakening the cultivation of practical ability. And this teaching model places too much emphasis on the continuity of theoretical knowledge systems, classroom teaching did not combine the work situation and practice teaching in a timely manner, it is only after some theory has been taught that an experimental class is arranged, or, after the completion of the theoretical teaching of the entire course, concentrate on arranging professional practice. The students are unable to contact the material object while learning the theory of the specialty, lack of perceptual cognition, make it more difficult for students to understand the theoretical knowledge of the memory professional. In practice teaching, because of the time difference, students have forgotten or blurred the contents of the theoretical class, unable to connect theory with reality, thus it weakens the training effect of the students' practical application ability, resulting in the separation of students in theoretical and practical learning out of touch. ${ }^{[4]}$

Therefore, the traditional teaching mode can no longer meet the educational requirements of the application-oriented undergraduates' emphasis on practice and application ability. It is necessary to actively explore the teaching model which is innovative and suitable for the characteristics of applied 
undergraduate education.

\section{Integrated On-Site Teaching Model of Theory and Practice}

Integrated on-site teaching model of theory and practice is based on the ability-based teaching model. It is no longer just a teacher-centered, teacher-based teaching model that completes knowledge transfer, but a teaching process that integrates teaching, learning and doing. In the classroom, the students not only obtained the theoretical knowledge of the teacher but also experienced the actual hands-on operation against the actual objects. And in the process, practical skills have been improved. The most important feature of this kind of integrated teaching and learning model is that while studying theoretically, students are provided with numerous visual and practical teaching equipments in the same place. It emphasizes the timeliness of the combination of theory and practice, students have improved their understanding of theoretical knowledge by learning and practicing on the scene, cultivate students' abilities and habits to apply theories to practice.

Automotive service engineering is an applied undergraduate major, cultivated students must have deep professional theories and have the practical ability to apply knowledge and technology in production, service, management, and other practical applications. Therefore, the integrated on-site teaching model of theory and practice is one of the effective teaching modes suitable for the automobile service engineering major. ${ }^{[5]}$

\section{Application of Theory and Practice Integrated On-Site Teaching Model in Automobile Service Engineering Teaching}

Optimizing the Curriculum System. Curriculum system refers to different courses of the same specialty, arranged according to categories., it's the sum of the content and the process of teaching Aiming at training application ability of applied automotive service engineering professionals. Is the guiding idea of educating people and is the embodiment and support of training objectives, it is the carrier that realizes the cultivation goal and is the key to guarantee and improve the quality of education. ${ }^{[6]}$ Actively carrying out the reform of education and teaching, gradually forming a curriculum system compatible with the requirements of modern automotive service engineering applied talents. Not all courses are suitable for integrated on-site teaching model of theory and practice, therefore, we should reasonably choose the content or curriculum that can implement the practical integration of on-site teaching. Finally, we sorted out a group of courses with high skill requirements and strong practicality, which is suitable for the on-site teaching mode based on integration of theory and practice. See table 1.

Table 1 The courses suitable for integrated teaching model

\begin{tabular}{|l|l|}
\hline serial number & course \\
\hline 1 & automobile engine structure \\
\hline 2 & automobile chassis structure \\
\hline 3 & automobile electric appliance \\
\hline 4 & automobile detection and diagnosis technology \\
\hline 5 & automobile maintenance engineering \\
\hline 6 & automobile electronic control technology \\
\hline 7 & new energy automobile technology \\
\hline
\end{tabular}

Making Syllabuses and Writing Handouts. Syllabuses is a teaching guidance document compiled according to the contents of the discipline and the requirements of its teaching plan. It stipulates the 
teaching purpose and task of curriculum in the form of outline, and the scope of knowledge and skill. It is the main basis for compiling teaching materials and teaching work, as well as an important criterion for checking students' academic achievements and evaluating teachers' teaching quality. ${ }^{\left[{ }^{[7}\right.}$ According to the theory and practice integrated on-site teaching content and professional certification requirements, we ascertain the instructional objectives, rewrite course syllabus. Based on reference materials, combine the actual situation of teaching to compile learning handouts, to ensure good teaching effect.

Construction of Integrated Classroom. We set the integrated classroom in the professional laboratory. According to the actual situation of the school, we have designed two kinds of integrated classrooms. One is automobile engine construction, vehicle chassis construction, automotive electrical appliances and other structural courses, directly placing the classroom in the corresponding laboratory, integrate theoretical teaching area and grouping training area, form a fixed integrated on-site teaching classroom. The other classrooms such as "automobile detection and diagnosis" and "automobile maintenance engineering" are set up in the same training workshop, supporting movable equipment and tables and chairs, so that it can be arranged flexibly and save space. ${ }^{[8]}$

Construction of Teacher Team. The development of integrated on-site teaching model requires a "dual-qualified" teacher team with deep and solid theoretical foundation and strong professional practice ability, however, the proportion of "academic" teachers is too large in most universities, and the shortage of "technical" teachers is serious. Therefore, in order to build a team of teachers who are suitable for integration of theory and practice, we formulate relevant incentive policies to improve teachers' initiative, establishing a scientific evaluation system to enhance the evaluation orientation of teachers' practical teaching ability. For specific practice projects, please come in and go out, that is, with the help of school enterprise cooperation platform, employing key technical personnel of the enterprise to serve as practical guidance teachers in the university or training and instruction for professional teachers, and dispatching professional teachers to the enterprise for post training. ${ }^{\text {[9] }}$

Table 2 practice skill assessment form of automobile inspection and diagnosis technology Project: wheel tire dynamic balance test

\begin{tabular}{|c|c|c|c|c|c|}
\hline Class: & \multicolumn{2}{|l|}{ Name: } & \multicolumn{3}{|l|}{ Student ID: } \\
\hline step & assessment points & proportion & deduction score standard & record & score \\
\hline \multirow[t]{3}{*}{ preparations } & $\begin{array}{l}\text { clear the soil, stones and } \\
\text { old balance blocks on the } \\
\text { measured wheels }\end{array}$ & \multirow[t]{3}{*}{20} & do not deducted 10 points & & \\
\hline & $\begin{array}{l}\text { according to the size of } \\
\text { the center hole of the rim, } \\
\text { choose the taper plate }\end{array}$ & & selection error deducted 5 points & & \\
\hline & $\begin{array}{l}\text { load the wheel and lock it } \\
\text { tight }\end{array}$ & & $\begin{array}{lll}\begin{array}{l}\text { installation error deducted } 10 \\
\text { points }\end{array} & & \\
\end{array}$ & & \\
\hline \multirow[t]{4}{*}{ testing } & $\begin{array}{l}\text { measuring related } \\
\text { parameters with a ruler on } \\
\text { a balance machine }\end{array}$ & \multirow[t]{4}{*}{50} & $\begin{array}{l}\text { the measurement method is } \\
\text { incorrect deducted } 10 \text { points }\end{array}$ & & \\
\hline & $\begin{array}{l}\text { put down wheel guard } \\
\text { and start testing }\end{array}$ & & error deducted 5 points & & \\
\hline & reading unbalanced data & & error deducted 5 points & & \\
\hline & $\begin{array}{l}\text { install balance weights as } \\
\text { instructed }\end{array}$ & & $\begin{array}{l}\text { omissions item deducted } 10 \\
\text { points. Operation error deducted } \\
10 \text { points }\end{array}$ & & \\
\hline retest & $\begin{array}{l}\text { recheck after installing } \\
\text { balance weight }\end{array}$ & 20 & $\begin{array}{l}\text { not done deducted } 10 \text { points. } \\
\text { operation error deducted } 10 \\
\text { points }\end{array}$ & & \\
\hline \multirow[t]{2}{*}{ finish } & $\begin{array}{l}\text { remove } \\
\text { assembly }\end{array}$ & \multirow[t]{2}{*}{10} & operation error deducted 5 points & & \\
\hline & cleaning tools and sites & & not done deducted 5 points & & \\
\hline
\end{tabular}

Assessment. Examination is an important part of teaching process and an important means to evaluate students' learning effect. ${ }^{[10]}$ The integrated on-site teaching model of theory and practice requires equal 
emphasis on theory and practice, therefore, the assessment content consists of three parts: professional theoretical knowledge assessment, practical skills assessment, normal performance and homework. Among them, professional theoretical knowledge accounted for $35 \%$ of the total score of the course, practical skills accounted for $35 \%$ of the total score of the course, and the usual performance and homework accounted for $30 \%$ of the total score of the course. The content of practical skills examination is different due to different curriculum contents, But the content of the examination is carefully designed. For example, in order to assess students' wheel tire dynamic balance testing skills, we designed 4 links. See table 2.

\section{Conclusion}

The automotive service engineering major based on applied talent cultivation is a newly established specialty, the teaching system is not very mature yet, the task of teaching reform is arduous and a long way to go. The integration of theory and practice teaching mode just fits the training requirement of "thick theory, strong skill" applied talents, it helps to enhance students' understanding of professional knowledge and enhance their practical ability. And it is suitable for the needs of automobile service engineering, Worth popularizing.

\section{References}

[1] Information on http://www.sohu.com/a/217173547_100039896.

[2] T.Sh. Deng: Journal of Jilin Engineering Normal University, Vol. 33(2017) No.7, p.1. (In Chinese).

[3] L.M. Zheng, J,H, Wen and Sh.W. Liu: Journal of Liaoning University of Technology(Social Science Edition), Vol. 15 (2014) No.5,p.129. (In Chinese).

[4] X.L Xu,Y.P. Jiang and Y. Zhang: Guangxi Journal of Light Industry, (2015) No.7,p.59. (In Chinese).

[5] Sh.W. Liu,L.M .Zheng and G. Li: Journal of Liaoning University of Technology(Social Science Edition), Vol. 14 (2012) No.3,p.130. (In Chinese).

[6] Ch.B. Liu,Sh.W. Guan and Y.D. Du: Contemporary Education Research and Teaching Practice, (2018) No.4,p.16. (In Chinese).

[7]X.Y. Sun: Southern Cultural Forum, (2018) No.3,p.9. (In Chinese).

[8] J. Liu: Journal of Guiyang College(Natural Sciences Quarterly Dec), Vol. 7(2012) No.4,p.75. (In Chinese).

[9] Zh.Ni, Sh.Zh. Bei and L.Ch. Zhang: Contemporary Education Research and Teaching Practice, (2017) No.8,p.180. (In Chinese).

[10]G.J. Qu,Ch.F. Yang and D. Zhang: Animal Husbandry and Feed Science, Vol. 35 (2014) No.9,p.51. (In Chinese). 